\title{
Islamic communication system in Republic of Indonesia
}

\author{
${ }^{1}$ Khurotin Anggraeni \\ ${ }^{1}$ Lecture of Faculty Da'wah and Islamic Communication \\ Institute for Islamic Studies (IAI) Pangeran Diponegoro Nganjuk East Java \\ Republic Indonesia \\ ${ }^{1}$ khurotin_anggraeni@iaipd-nganjuk.ac.id
}

\begin{abstract}
The Indonesia is various cultures and language, Islam is a biggest religion in Indonesia, the communication form of Islam to understanding Islamic religion in various regions which has various culture and language. Islamic Communication system is a social action between Islamic organization with exchanging idea and raising the expectation of recognizing, understanding, acceptable to achieve specific goal (Da'wah) with multifaceted undertaking which require careful assessment of requirements, technology alternative, the allocation resources, economic impact and religion impact. The purpose of study is to describe and analysis Islamic communication system in Republic of Indonesia. The research method is done by library and information studies literature published was examined using content analysis method. The process included several steps: determining which journals and books met the inclusion criteria; selecting the research articles from the included journals and book; and extracting data from the relevant articles. As we know Indonesia has limit transportation and communication technology, very large area and has different language, culture and religion. The result of Islamic communication system is organization as problem solved on communication system. Islamic organization with multifaceted undertaking is required careful assessment on technology information, allocation resources, economic impact and religion impact. The role figure of leadership (usually namely Kyai) in communication is very important to connect with same organization. Interaction linkages between organizations will raise expectation on recognizing, understanding and acceptable..
\end{abstract}

Key word: Islamic Communication, Communication system

\section{INTRODUCTION}

The Indonesia is various cultures and language. According to the U.S. Library of Congress, more than 650 different languages and dialects are spoken in the country. The partition of Indonesia by water has often made interisland communication. ${ }^{i}$ Someone needs extra-communication to understand and make sense to communication with various regions. Thus, local languages such as Javanese, Balinese, Sasak, and Sundanese are still used in some areas, although Bahasa Indonesia serves as the national and unifying language. ${ }^{\text {ii }}$ Not only culture and language are various in Indonesia but also religion. 
Islam is a biggest religion in Indonesia, more than 230 million people, ranks fourth among the world's countries in population. In addition, a staggering 88 percent of its people, more than 200 million, are Muslim. This is about the same number of Muslims as the nations of Egypt, Iraq, Iran, Saudi Arabia, Syria, Lebanon, and Jordan combined. In other words, Indonesia has nearly the same number of Muslims as the entire Middle East. iii Indonesia as world spotlight because has the biggest Muslim and as safe and peaceful country although, multifaceted religion, culture and language. There are many jealous country with Indonesia therefor they want divisive Indonesia with make an issue like religious and culture. This is a challenging for Indonesia to maintain the integrity of the nation. Not only the nation but also religious especially Islam which take challenging as maintain religious existence. The form to keep religious existence is communication.

Communication is an instrument for maintain religious existence and unity multifaceted culture, language and religion. From communication, they (Indonesia society ) understanding about Islam and as the biggest religion in Indonesia. From that phenomenon the researcher interested to know communication system form especially in Islam until the biggest religion in Indonesia and how Islamic religion understand Indonesia society to understand their religion whereas Indonesia has various language, culture and religion. What is communication system implemented by Islamic religion?.

From the phenomenon above, the researcher interest to study with the title "Islamic Communication System of Republic Indonesia" with research question how is Islamic communication system in republic of Indonesia. The purpose of study is to describe and analysis Islamic communication system in Republic of Indonesia.

\section{LITERATURE REVIEW}

\section{Communication System}

Communication is the process of exchanging feelings and ideas. ${ }^{\text {iv }}$ Communication is required between two persons. ${ }^{\mathrm{v}}$ Communications is a vast field, and it would be futile to try to gain expertise in every aspect. ${ }^{\mathrm{vi}}$

System definition is a set of object or element in interaction to achieve specific goal. $^{\text {vii }}$ System is a multifaceted undertaking that requires careful assessments of requirements, technology alternatives, the allocation of resources, and economic impacts. ${ }^{\text {vii }}$

Luhmann's autopoietic communication theory is defined into three are: first, actions need not be inherently social whereas communications although this does verge on the tautological (replay ideas) since the social is defined as a system of communications. Second, social actions already presuppose communications in the sense that they rely on or raise the expectation of recognition, understanding, and acceptance by others. third a communication is more than simply an action. ${ }^{\text {ix }}$ 


\section{J'KÍs \\ e-ISSN 2797-1619 \\ http://ejurnal.iaipd-nganjuk.ac.id/index.php/j-kis/

Communication system is a social action on interaction between two or more person with exchanging feeling and idea raising the expectation of recognize, understanding, acceptable to achieve goal with multifaceted undertaking which require careful assessment of requirement, technology alternative, the allocation of resources and economic impact.

Islamic theory of communication based on a narrow and essentialist conceptualization of 'authentic' culture, a particular communication theory that is more pertinent to Muslim Societies, is the latest and most telling of the 'Islamic Studies' ${ }^{x}$ Islam is a communication based religion, then like any religion, is facing many challenges to evolve and adjust to modernity and in particular to the economic and cultural power of a dominant West. Islam is a communicative religion, and Allah is communicative Allah who takes keen interest in the affairs of His creatures. ${ }^{x i}$ The rules and regulations of communication among human being as it was mentioned in Holy Qur'an and Sunnah of prophet Mohammed. Therefore, this chapter presents first, the origin of language in Islam and the theoretical perspective of communication model and theory in early and current Islamic arena ${ }^{\text {xii }}$

Islamic Communication system is social action between Islamic organization with exchanging idea and raising the expectation of recognizing, understanding, acceptable to achieve specific goal (Da'wah) with multifaceted undertaking which require careful assessment of requirements, technology alternative, the allocation resources, economic impact and religion impact.

The Classification of communication system based on the requirements, the communications system can be classified into six categories, ${ }^{x i i i}$ three types as part in another sources are: ${ }^{\text {xiv }}$

a. Point-to-point communication: In this type, communication takes place between two end points. For instance, in the case of voice communication using telephones, there is one calling party and one called party. Hence the communication is point-to-point.

b. Point-to-multipoint communication: In this type of communication, there is one sender and multiple recipients. For example, in voice conferencing, one person will be talking but many others can listen. The message from the sender has to be multicast to many others.

c. Broadcasting: In a broadcasting system, there is a central location from which information is sent to many recipients, as in the case of audio or video broadcasting. In a broadcasting system, the listeners are passive, and there is no reverse communication path.

The part same other sources

d. Simplex communication is a unidirectional communication system. Communication is possible in one direction only. Typically, the transmitter (the one talking) sends a signal and it's up to the other receiving device (the listener) 
to figure out what was sent. Broadcast systems like the T.V and radio signals, fire alarm systems etc.

e. Half Duplex is a bidirectional communication is possible, but only in one direction at a time, means one can either transmit or receive a signal at a particular instant of time in this system of communication.

f. Full Duplex is communication system simultaneous two-way communication is achieved

The objective of designing a communication system is for the electrical signal at the transmitting end to be reproduced at the receiving end with minimal distortion. $^{\mathrm{xv}}$ Communication systems are designed to specific availability requirement. ${ }^{\text {xvi }}$ The various functions to be carried out in a communication system are: multiplexing, multiple access, error detection and correction, source coding, switching and signaling. ${ }^{\text {xvii }}$

Communication systems can be broadly divided into analog communication systems and digital communication systems. In analog communication systems, the analog signal is transmitted. In digital communication system, even though the input signal is in analog form, it is converted into digital format and then sent through the medium. For a noise condition, the digital communication system gives better performance than the analog system. All the newly developed communication systems are digital systems. Only in broadcasting applications, is analog communication used extensively. ${ }^{\text {xiii }}$

\section{Islamic Communication In Indonesia}

Arab traders carried Islam to Indonesia from the twelfth to the fifteenth centuries. First contacts were in Sumatra, Kalimantan, and northern Java. Islam is a biggest religion in Indonesia, more than 230 million people, ranks fourth among the world's countries in population. In addition, a staggering 88 percent of its people, more than 200 million, are Muslim. Islam is the dominant religion in Indonesia, and the country has the world's largest Muslim population. Eighty-eight percent of the citizens are Muslim, but the government allows other religions to exist. Included within these other government-sanctioned religions are Protestants (5 percent), Roman Catholics ( 3 percent), Hindus ( 2 percent), and Buddhists ( 1 percent). Only one percent of the population falls into the "Other" category of nonreligious or people holding other beliefs. ${ }^{\text {xix }}$

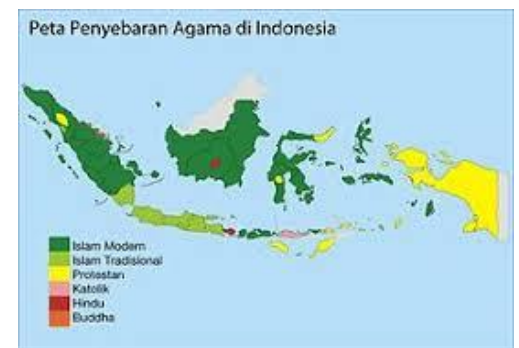

Figure 1. Map Religious Distribution in Indonesia 
The Indonesia is various language and culture, more than 650 different languages and dialects are spoken in the country. The partition of Indonesia by water has often made interisland communication. Islamic religion needs extracommunication to understand and make sense to communication with various regions. The communication forms of Islam to understanding Islamic religion in various regions which has various culture and language. According to Indonesia's 2000 census (the first to include ethnicity since 1930), more than 500 different ethnic groups live in the country. The Javanese are the largest group, followed by Sundanese, Malays, and Madurese. The country also has significant numbers of Chinese, Minangkabau, Batak, Buginese, Balinese, Ambonese, Dayaks, and Sasaks. Many of the ethnic groups, like the Javanese, Balinese, and Ambonese. ${ }^{x x}$

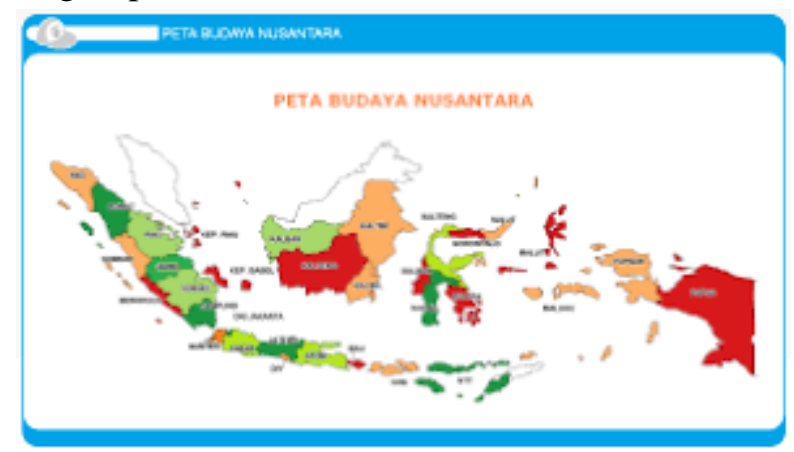

Figure 2. Culture Division Map

Indonesia is a place with limited transportation and communication technology. These are some of the factors that can severely restrict contact with neighbors, even though they may live only a few miles away. Today, with cell phones, satellite technology, the Internet, aircraft, sophisticated ships, and other transportation systems, people have been able to overcome many of the challenges posed by their environment. ${ }^{x x i}$ Opportunity to visit neighboring islands without risking life or injury because of the dangerous ocean waters that separated communities. Others were unable or elected not to cross the difficult mountainous terrain, even when they were on the same island. These factors fostered the development of different cultures (people with different ways of living), even though the groups may be only miles apart. New technologies have helped people bridge these barriers and connect in ways not possible a few decades ago. ${ }^{\text {xxii }}$ 


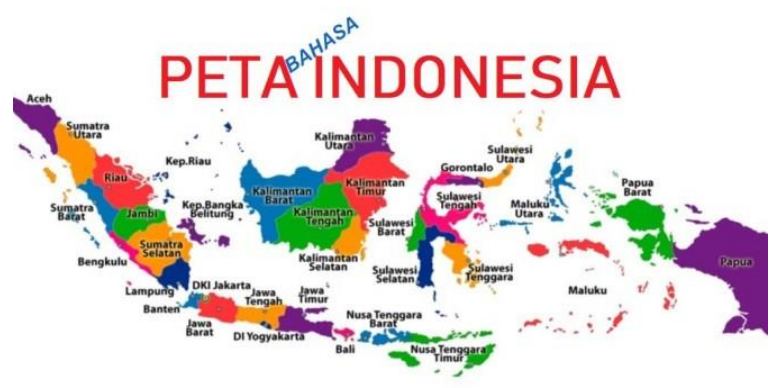

Figure 3. Map Language Distribution

Islamic communication in Indonesia to understanding, unite and attract. The large Muslim population, the law is sometimes complex because Sharia law, moral law from the most holy book of Islam, the Koran, often plays an important role in local courts. Muslim influence in the government and the introduction of Shar'iah law, government has never been in the hands of leaders determined to identify the state with Islam. On the contrary, the state ideology of Pancasila (Five Principles) embodies a vision of a pluralist state in which no particular religion is endowed with special privileges. ${ }^{\text {xiii }}$ There has been a steady rise in Muslim consciousness and ritual formalism, especially among the urban middle classes and student population. University campuses have become fertile ground for an Islamic awakening, with students being recruited into a diverse range of disciplined organizational cells. ${ }^{\text {xiv }}$

The vision and mission of Islam Indonesia is Dakwah. ${ }^{\mathrm{xxv}}$ Dakwah is the Indonesian term for the Islamic concept of the call or invitation to follow the path of Allah. A common way of translating Dakwah is missionary work, or propagation of the faith. Like Harold Lasswell's famous model of communication, dakwah has five components: the $d a^{\prime} i$, or the person engaged in Dakwah; the mad'u, or target audience; the channel of communication; the message; and the effect. ${ }^{\text {xxvi }}$ Dakwah is a fundamental activity of Indonesian state Islamic institutes and universities. Communication is something close to dakwah; the meaning of dakwah is to give a message to non-Muslims. ${ }^{\text {xxii }}$

The model communication (dakwah) incorporated organization form. Islamic organisations in Indonesia belong to the Sunni branch of orthodoxy, originating in the Arab hinterlands, as opposed to the splinter branch of Shi'ism, which spread to parts of Persia. Indonesian orthodoxy has coalesced into two major movements: the kaum muda ('young group') or santri moderen (modernists) and kaum tua ('old group') or santri kolot (the traditionalists). Islamic modernism in Indonesia grew out of an Egyptian reform movement and in response to early indigenous nationalism at the turn of the century. It drew substantial inspiration from the reform ideas of the anti-colonial, pan-Islamist Jamal al-Din al-Afghani (1839-1897) and the 'Father of Modernism' Muhammad Abduh (1845-1905). 
Representing Islamic modernism at home were organisations such as Sarekat Islam (United Islam, SI) and the Muhammidayah, both founded in 1912, and Persatuan Islam (Unity of Islam, Persis) founded in 1923. The modernist organizations mostly catered to a socioeconomic class of educated urban elites and merchant traders. They gave priority to education, social welfare programs and dakwah (religious propagation) activities. Muhammadiyah is the main modernist organisation today with an estimated 28 to 30 million members. It was founded in Yogyakarta (Central Java) by K.H.Ahmad Dahlan, Two prominent religious scholars (kiai), Wahab Chasbullah and Hasjim Asj'ari founded the Nahdlatul Ulama (Revival of the Religious Scholars, NU) in 1926Two prominent religious scholars (kiai), Wahab Chasbullah and Hasjim Asj'ari founded the Nahdlatul Ulama (Revival of the Religious Scholars, NU) in 1926 in order to protect the economic and socialreligious interests of pesantren (religious boarding schools) NU has an estimated membership of over 30 million people. ${ }^{\text {xxvii }}$

\section{RESEARCH METHOD}

Library and information studies literature published was examined using content analysis method. The process included several steps: determining which journals and books met the inclusion criteria; selecting the research articles from the included journals and book; and extracting data from the relevant articles. ${ }^{\text {xxix }}$ Investigators compiled a comprehensive list of potential journals and for inclusion in the study. Article inclusion/exclusion was done independently by two researchers using a standard inclusion/exclusion. The form and A standardized form was used to capture data about: the domain; research method(s); study objective; author affiliation and country; abstract inclusion and whether the abstract was structured; literature review inclusion; and research funding.

\section{DISCUSSION}

Islamic communication system in Indonesia is a social action between Islamic organization with exchanging idea and raising the expectation of recognizing, understanding, acceptable to achieve specific goal (Da'wah) with multifaceted undertaking which require careful assessment of requirements, technology alternative, the allocation resources, economic impact and religion impact where take a place in Indonesia. Indonesia is large area which various language 650 different languages, various cultures 500 different ethnic groups live and various religion 6 difference religions allow in Indonesia.

Islam come to Indonesia from the twelfth to the fifteenth centuries $^{\mathrm{xxx}}$ dominant religion in Indonesia 88 percent of its people, more 
than 200 million, are Muslim. ${ }^{\text {xxxi }}$ The biggest religion Indonesia is not easy; there a strategy is done by Muslim to a biggest religion. First of all is communication, communication is very important made Indonesia society understand about Islamic religion especially in system communication, as we know that Indonesia is very large area and has different language, culture and religion.

Indonesia is a place with limited transportation and communication technology. ${ }^{\text {xxxii }}$ Since 12 century when Islam come to Indonesia. Communication only a few miles away even though the groups may be only miles apart, through a little group an area will make a small organization. The small organization with a leadership figure will connect with other organization with same purpose. The small organization is a pioneer the big organization. The role figure of leadership (usually namely Kyai) in communication is very important to connect with same organization, as we know Indonesia has limit transportation and communication technology, very large area and has different language, culture and religion. It's impossible that communication with individually consider with large area, different language and culture to learning Islam. The effective communication in Indonesia with limit transportation and communication technology is made a group in area or organization.

Through organization is problem solved on communication system. Islamic organization approximately 35 organizations xxxiii includes: Nahdlatul Ulama (NU), Muhammadiyah, Al Irsyad Al Islamiyyah, Al Ittihadiyah, Al Washliyah, Dewan Dakwah Islamiyah Indonesia (DDII), Dewan Masjid Indonesia (DMI), Forum Umat Islam (FUI), Front Pembela Islam (FPI), Forum Dakwah Islam Indonesia (FDII), Gerakan Pemuda Ansor, Himpunan ahlus Sunnah Untuk Masyarakat Islami (Hasmi), Hidayatullah, Hizbut Tahrir Indonesia (HTI), Ikatan Cendekiawan Muslim Indonesia (ICMI), Ikatan Da'i Indonesia (Ikadi), Lembaga Dakwah Kemuliaan Islam (LDKI), Lembaga Dakwah Islam Indonesia (LDII), Majelis Intelektual dan Ulama Muda Indonesia (MIUMI), Majelis Az Zikra, Majelis Dakwah Islamiyah, Majelis Ulama Indonesia (MUI), Majelis Tafsir Al-Quran (MTA), Mathla'ul Anwar, Nahdlatul Wathan (NW), Pemuda Muslimin Indonesia, Persatuan Islam (Persis), Persatuan Islam Tionghoa Indonesia (PITI), Persatuan Ummat Islam (PUI), Persatuan Tarbiyah Islamiyah (Perti), Syarikat Islam (SI), Wahdah Islamiyah, BP4. The Islamic organization has difference way to Da'wah but they have same aim Da'wah. The organization is media communication effective to accommodate society (Ummah) to extend their aspiration and learning about Islam. Every organization has branch in every area in Indonesia which will connect with center their organization. The form connects of organization will make linkages. The linkages in Islamic organization are a form of communication system or Islamic Communication system. The Islamic communication system can be seen in Figure 1. 


\section{JKÍ⿴囗十

Interaction linkages between organizations will raise expectation on recognizing, understanding and acceptable. Social organization interaction linkage has characteristic autopetic or open ${ }^{\text {xxiv }}$ which exchange feeling and raising the idea to a mission. Linkage in Islamic organization is between 35 Islamic organizations. The way of interaction linkage can classify into two part include manual and using technology: manual can divide into point to point that individual communication such as someone communication with Islamic figure (Kyai) to solve their problem with Islamic knowledge with individual communication or kyai communication with kyai from other Islamic organization, point to multiple such as Islamic figure (Kyai) talk with two or more (kyai) with small group, broadcast with many recipient or social such as kyai dakwah in public or with all Islamic organization. Using technology, as we know that Indonesia has limited technology communication, Indonesia just using simplex is communication using broadcast system such as TV, radio etc, Indonesia star up to develop into Half Duplex and Full Duplex. Linkages 35 Islamic organization form can understanding and acceptable in social community because of figure (kyai) in each organization and each area who understanding each language, culture and come into Da'wah cross religion.

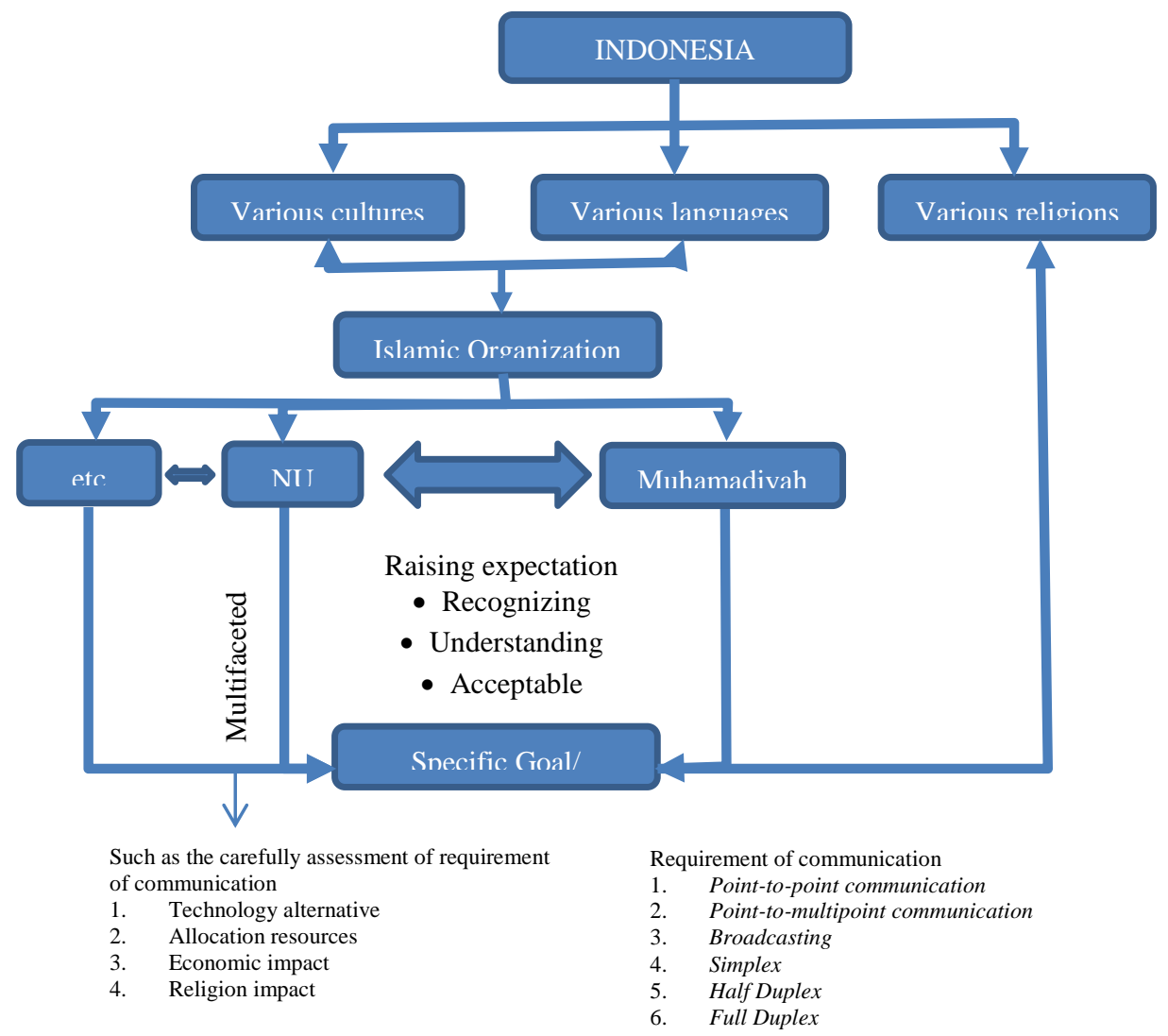

Figure 1. Islamic Communication System in Indonesia Social action interaction between Islamic Organization. Source: own 
To get specific goal the Islamic organization with multifaceted undertaking is require careful assessment of requirements such as technology alternative, allocation resources, economic impact and religion impact.

1. Technology information

Indonesia nowadays has technology information with cell phones, satellite technology, the Internet, aircraft, sophisticated ships, and other transportation systems, Islamic organization have been able to overcome many of the challenges. ${ }^{\mathrm{xxv}}$ Indonesia is developing country where technology information as challenging. Islamic organization will develop on this challenging, such as organization of Nahdatu Ulama (NU) has make a breakthrough via website ${ }^{\mathrm{xxxvi}}$ NUonline, radio-NU and TV-NU, Organization of Muhamadiyah has website Suara muhamadiyah and lembaga penelitian dan pengembangan (research and development), formed majelis pustaka dan informasi, Organization Lembaga Dakwah Islam Indonesia (LDII) has website ${ }^{\text {xxxvii }}$, TV ldii, organization hidayatullah has magazine hidayatullah

Present a structure framework for electric utilities who pan to utilize new communication technologies for automation and hence to make the decision making process more effective and direct. ${ }^{\text {xxviii }}$ Prospective communications professionals need to have a strong foundation in digital communication and data communication protocols, as well as an exposure to the latest technological innovations. ${ }^{\text {xxxix }}$

2. Allocation resources

- Muslim influence in the government and the introduction of Shar'iah $\operatorname{law}^{\mathrm{xl}}$

Indonesia Muslim has introduction Shar'iah law which merges with Indonesia culture and Indonesia law is done when Indonesia independent which the biggest Islamic organization arrange such as Nahdatul Ulama (NU) and Muhamadiyah it time as biggest organization, it is proven NU build mendirikan Lembaga Penyuluhan dan bantuan hukum NU (LPBH-NU) or counseling and legal aid institution and halal institution or Lembaga Badan Halal Nahdatul Ulama (LBH-NU). While Muhamadiyah build assembly law and human right or majelis hukum dan hak asasi manusia. This institution was no other new Islamic organization

- The law is sometimes complex because Sharia law, moral law from the most holy book of Islam, the Koran, often plays an important role in local courts. ${ }^{\text {xli }}$ The Indonesia foundation law or PANCASILA based on collaboration Islamic law and value of Indonesia culture.

- University campuses have become fertile ground for an Islamic awakening, with students being recruited into a diverse range of disciplined organizational cells. ${ }^{\text {xli }}$ Islamic organization cell not only 


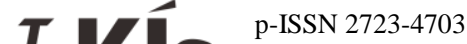

in Islamic campus but also non Islamic/general/state campus such as from muhamadiyah corporate with HMI (Himpunan mahasiswa Islam), IMM (Ikatan Mahasiswa muhamadiyah), from Nahdatul Ulama corporate with PMII (Persatuan mahasiswa Islam Indonesia), IPNU-IPPNU (ikatan pelajar Nahdatul ulama), ISNU Ikatan sarjanah nahdatul ulama), etc

- Dakwah is a fundamental activity of Indonesian state Islamic institutes and universities ${ }^{\text {xliii }}$ it is provent with Nahdatul ulama build education institution and university namely pesantren ( Rabitah Maahid IslamiyahNU RMI-NU, lembaga asosiasi pesantren NU)as non-formal education, and formal education from kindergarten (PIAUD) until university incorporate on Education institution ma'arif NU). The same is done by Muhamadiyah focul on formal education from kindergarten (PAUD) until university incorpoprate with assembly primary and high school ( majelis pendidikan dasar dan menengah) and assembly higher education (majelis pendidikan tinggi). LDII has pesantren, and Hidayatullah has pesantren hidayatullah,

\section{Economic Impact}

The modernist organizations mostly catered to a socio economic class of educated urban elites and merchant traders. They gave priority to education, social welfare programs and dakwah (religious propagation) activities. NU, Muhamadiyah and Islamic organization protect the economic and social-religious interests of education or pesantren. ${ }^{\text {xliv }}$ And Islamic organization has economic institution such as: Nahdatul Ulama (NU) has Lembaga Perekonomian NU (LPNU), Lembaga pengembangan pertanian NU (LPP-Nu), Lembaga pelayanan kesehatan NU (LPK-NU) lembaga kemaslahatan keluarga NU (LKK-NU), serikat buruh muslim Indonesia (SARBUMUSI). Muhamadiyah build assembly general helth coaching (majelis pembinaan kesehatan umum) with build hospital, and assembly social service (majelis pelayanan sosial) such as orphanage, disaster management institute (lembaga penanggulangan bencana) and assembly economic and entrepreneur (majelis ekonomi dan kewirausahaan). Hidayatullah has Islamic medical service, cooperative hidayatullah and program community empowerment inland (program pemberdayaan masyarakat pedalaman). ${ }^{\text {xlv }}$

4. Religion Impact

- Islamic communication in Indonesia to understanding, unite and attract 
Islamic idiologi spread through Islamic organizations in Indonesia can acceptable by Indonesia society because of da'wah without violence and truth doctrine. There are many organization shade small institution such as: Nahdatul Ulama (NU) shade many institution following: JATMAN, Muslimat NU, GP Anson NU, Fatayat NU, KMNU, IPNU, IPPNU, ISNU, IPSNU Pagar Nusa, JQHNU dan Pergunu. Muhamadiyah also shade institution following: Aisyiyah, Pemuda Muhamadiyah, Nasyiatul Aisyiyah, Ikatan Pelajar Muhamadiyah (IPM), Ikatan Mahasiswa Muhamadiyah (IMM), Hizbul Wathan (gerakan pramuka), Tapak Suci Putra Muhamadiyah.etc xlvi

- The vision and mission of Islam Indonesia is Dakwah (Dakwah is the Indonesian term for the Islamic concept of the call or invitation to follow the path of Allah) ${ }^{\text {xlvii }}$.Nahdatu Ulama has Da'wah institution (lembaga dakwah nahdatul ulama (LD-NU)) and Muhamadiyah has assembly Da'wah (majelis tarjih dan tajdid dan majelis tabliq).

\section{RESULT}

Islam as dominant religion in Indonesia 88 percent of its people, more than 200 million, are Muslim, there a strategy is done by Muslim to a biggest religion following. First of all is communication, communication is very important made Indonesia society understand about Islamic religion especially in system communication, as we know that Indonesia is very large area and has different language, culture and religion. Indonesia is a place with limited transportation and communication technology. The role figure of leadership (usually namely Kyai) in communication is very important to connect with same organization, as we know Indonesia has limit transportation and communication technology, very large area and has different language, culture and religion.

Through organization is problem solved on communication system. Islamic organization with multifaceted undertaking is require careful assessment of requirements such as Technology information challenging, build research and development institution and breakthrough via website radio and television magazine etc. as communication technology and foundation digital communication technology and foundation digital communication technology innovation. Allocation resources (Muslim influence in the government and the introduction of Shar'iah law which marge Indonesia culture and Indonesia law when Indonesia independency

which biggest Islamic organization arrange Nahdatu ulama and Muhamadiyah with legal aid institution and law,human right institution, Pancasila based on collaboration Islam law and value Indonesia culture. University campuses have become fertile ground for an Islamic awakening, with students being recruited into a diverse range of disciplined 
organizational cells. Dakwah is a fundamental activity of Indonesian state Islamic institutes and universities). Economic Impact (Nahdatu Ulama, Muhamadiyah and Islamic organization protect the economic and socialreligious interests of education or pesantren and Islamic organization has economic institution direct on economic impact). Relegion impact (Islamic communication in Indonesia to understanding, unite and attract and The vision and mission of Islam Indonesia is Dakwah (Dakwah is the Indonesian term for the Islamic concept of the call or invitation to follow the path of Allah)

\section{CONCLUSION AND RECOMMENDATIONS Conclusion}

Islamic communication system in Republic of Indonesia is communication system is used Islamic religion to getting specific goal (Da'wah) in Republic of Indonesia, which Communication system in Indonesia which has large area which various language 650 different languages, various cultures 500 different ethnic groups live and various religion 6 difference religions allow in Indonesia and a place with limited transportation and communication technology. Through organization is problem solved on communication system. From the interaction between organizations is through many analysis or assessment such as technology information, allocation resources, economic impact and religious impact will raising expectation following recognizing, understanding and acceptable of Islam.

\section{Recommendation}

Islamic communication system in Republic of Indonesia must be attention on analysis technology information which create innovation, allocation resources with not only introduction on shar'iah law but also apply through education and research and development, economic impact bring Muslim prosperous and religion impact on get closer to Allah.

\section{REFERENCE}

' Douglas A. Phillips, Indonesia, Modern World Nations (Philadelphia: Chelsea House Publishers, 2005), 10.

${ }^{\text {ii }}$ Phillips, 10.

${ }^{\text {iii }}$ Phillips, 10.

iv Apurba das, Line Communication System, new age international publishing (new delhi :2011)1

v Apurba Das, Digital Communication: Principles and System Modelling, Signals and Communication Technology (Heidelberg; New York: Springer, 2010). 
${ }^{\mathrm{vi}}$ K. V. K. K. Prasad, Principles of Digital Communication Systems and Computer Networks, 1st ed, Engineering Series (Hingham, Mass: Charles River Media, 2003), 7.

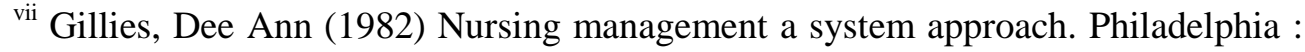
w.B Saunder Company

${ }^{\text {viii }}$ Robert Dybdal, Communication Satellite Antennas. (New York, USA: McGrawHill Professional Publishing, 2009), xiv, http://public.eblib.com/choice/publicfullrecord.aspx?p=4657530.

ix John Mingers, Realising Systems Thinking: Knowledge and Action in Management Science, Contemporary Systems Thinking 14 (New York, NY: Springer, 2006).

${ }^{x}$ Gholam Khiabany, "Is There an Islamic Communication? The Persistence of 'Tradition' and the Lure of Modernity," Critical Arts 21, no. 1 (July 2007): 10624, https://doi.org/10.1080/02560040701398814.

${ }^{x i}$ Dr. Amal Ibrahim Abd El-Fattah Khalil, "The Islamic Perspective of Interpersonal Communication," Journal of Islamic Studies and Culture 4, no. 2 (2016), https://doi.org/10.15640/jisc.v4n2a3.

xii Khalil.

xiii Prasad, Principles of Digital Communication Systems and Computer Networks, 14.

${ }^{\text {xiv }}$ Apurba Das, Digital Communication: Principles and System Modelling, Signals and Communication Technology (Heidelberg; New York: Springer, 2010)2.

${ }^{\mathrm{xv}}$ Prasad, Principles of Digital Communication Systems and Computer Networks, 10.

${ }^{x v i}$ Robert Crane, Propagation Handbook for Wireless Communication System Design, vol. 13, Electrical Engineering \& Applied Signal Processing Series (CRC Press, 2003), 11, https://doi.org/10.1201/9780203506776.

xvii Prasad, Principles of Digital Communication Systems and Computer Networks, 13.

xviii Prasad, 18.

xix Phillips, Indonesia, 42.

${ }^{\mathrm{xx}}$ Phillips, 10.

${ }^{x x i}$ Phillips, 46.

xxii Phillips, 46.

xxiii Donald J. Porter, Managing Politics and Islam in Indonesia (London; New York: RoutledgeCurzon, 2002), 1.

${ }^{\text {xxiv }}$ Porter, 24.

${ }^{\mathrm{xxv}}$ Janet Steele, "Journalism and 'The Call to Allah': Teaching Journalism in Indonesia's Islamic Universities and State Institutes,” 2012, 18. 
xxvi Ilaihi, W. (2010). Komunikasi dakwah [Dakwah communication]. Bandung, Indonesia: PT Remaja Rosdakarya.

${ }^{x x v i i}$ Steele, "Journalism and 'The Call to Allah': Teaching Journalism in Indonesia's Islamic Universities and State Institutes."

${ }^{x x v i i i}$ Porter, Managing Politics and Islam in Indonesia, 60-63.

${ }^{x x i x}$ Denise Koufogiannakis, Linda Slater, and Ellen Crumley, "A Content Analysis of Librarianship Research," Journal of Information Science 30, no. 3 (June 2004): 227-39, https://doi.org/10.1177/0165551504044668.

${ }^{\mathrm{xxx}}$ Phillips, 10.

xxxi Phillips, 10.

xxxii Phillips, 10.

xxxiii https://id.wikipedia.org/wiki/Daftar_organisasi_massa_Islam_di_Indonesia

xxxiv John Mingers, Realising Systems Thinking: Knowledge and Action in Management Science, Contemporary Systems Thinking 14 (New York, NY: Springer, 2006).

${ }^{\text {xxxv }}$ Phillips, 46.

${ }^{x x x v i}$ www.nu.or.id

xxxvii www.ldii.or.id

xxxviii V.C. Gungor and F.C. Lambert, "A Survey on Communication Networks for Electric System Automation,” Computer Networks 50, no. 7 (May 2006): 877-97, https://doi.org/10.1016/j.comnet.2006.01.005.

${ }^{\text {xxxix }}$ K. V. K. K. Prasad, Principles of Digital Communication Systems and Computer Networks, 1st ed, Engineering Series (Hingham, Mass: Charles River Media, 2003), 6.

${ }^{\mathrm{xl}}$ Donald J. Porter, Managing Politics and Islam in Indonesia (London ; New York: RoutledgeCurzon, 2002), 1.

${ }^{x l i}$ Donald J. Porter, Managing Politics and Islam in Indonesia (London; New York: RoutledgeCurzon, 2002), 1.

xlii Porter, 24.

xliii Janet Steele, “Journalism and 'The Call to Allah': Teaching Journalism in Indonesia's Islamic Universities and State Institutes," 2012, 18.

${ }^{\text {xliv }}$ Porter, Managing Politics and Islam in Indonesia, 60-63.

${ }^{\mathrm{xlv}}$ https://m.hidayatullah.com

xlvi www.muhammadiyah.or.id

xlvii Janet Steele, "Journalism and 'The Call to Allah': Teaching Journalism in Indonesia's Islamic Universities and State Institutes,” 2012, 18. 